Rui Lopes

\title{
An Oasis in Europe: Hollywood Depictions of Portugal during World War II
}

\begin{abstract}
In the early 1940s, the wave of North American fiction films dealing with the Second World War devoted unprecedented attention to Portugal, then a neutral nation under a fascist-inspired dictatorship led by António de Oliveira Salazar. This article analyses the underlying discourse about Portugal in the stories filmed by Hollywood during this period. It focuses on three key motifs, namely the portrayal of the country as an escape point for refugees, as a gathering ground for spies, and as a safe haven from European war and oppression. Besides identifying common patterns in the narratives, the article seeks to contextualise them by taking into account the evolution of the scripts, as well as the feedback from the Production Code Administration and the Office of War Information. It also briefly contrasts the portrayal of Portugal with that of Spain, where a similar political regime was in place. It concludes that the combination of Hollywood's formulaic narratives and Washington's propaganda strategy resulted in a depiction of Portugal that was patronising yet mostly benevolent, romanticising local living conditions and dissociating the Salazar dictatorship from its fascist origins and practices.
\end{abstract}

\section{Keywords}

Cinema, Fascism, Hollywood, Portugal, World War II 
The opening page of the final screenplay for the 1944 film The Conspirators ${ }^{1}$ evocatively established its setting:

Lisbon in $1944 \ldots$

To the men of enslaved countries, a mirage of peace and freedom - a symbol of escape from the horror that has swallowed them. The lucky few who manage to reach it find a precarious security and, all around them, a thousand eyes ceaselessly watching, a thousand ears ceaselessly listening... For Lisbon has become a city of echoes... shadows... hallucinations... ${ }^{2}$

Although these exact lines did not appear in the film, they captured the depiction of the Portuguese capital in this and other Hollywood productions of the early 1940s. During this period, the motion picture industry of the United States of America (USA) which despite wartime restrictions on most European countries retained the largest share of world screen time ${ }^{3}$ - took unprecedented notice of Portugal, the small neutral nation where António de Oliveira Salazar had established a dictatorship along fascist lines in 1933. ${ }^{4}$ However, while Portugal's interaction with the outside world in the context of the Second World War has been the object of varied historiographical studies, ${ }^{5}$ such a highly visible dimension of its international history remains largely unexplored. In order to help fill that gap, this article will examine the underlying discourse about Portugal in the stories told against its background by Hollywood fiction films produced between 1939 and 1945. ${ }^{6}$ It will focus on three key motifs, namely the portrayal of the country as an escape

\footnotetext{
${ }^{1}$ The Conspirators, Dir. Jean Negulesco, Warner Brothers, 1944.

2 Margaret Herrick Library at the Academy of Motion Pictures Arts and Sciences (AMPAS), Hal Wallis papers, 418, Conspirators, Revised final screenplay.

${ }^{3}$ K. Segrave, American Films Abroad: Hollywood's Domination of the World's Movie Screens from the 1890s to the Present (Jefferson, N.C. 1997), 119-39.

${ }^{4}$ The only previous productions set in Portuguese soil were The Last Flight (Dir. William Dieterle, First National Pictures, 1931), partly set in Lisbon; Hong Kong Nights (Dir. E. Mason Hopper, Walter Futter Productions, 1935), partly set in Macao; and Love Affair (Dir. Leo McCarey, RKO, 1939), partly set in Madeira. For a recent synthesis of the political postulates and practices of Salazar's regime, see F. Rosas, Salazar e o Poder: a arte de saber durar (Lisbon 2013).

${ }^{5}$ A. Louçã, Hitler e Salazar: comércio em tempos de guerra, 1940-1944 (Lisbon 2000); H.P. Janeiro, Salazar e Pétain: relações luso-francesas durante a Segunda Guerra Mundial, 1940-44 (Lisbon 1998); I. Pimentel, C. Ninhos, Salazar, Portugal e o holocausto, (Lisbon 2013); M. Teixeira, 'Caught on the Periphery: Portuguese Neutrality during World War II and Anglo-American Negotiations with Salazar', unpublished PhD thesis, University of Pennsylvania (2008).

${ }^{6}$ Because the main focus of this analysis are the implications of the ways in which the films were conceptualised, it will mostly engage with their subject matter and scripted narrative. The choice not to linger as much on other technical elements of filmmaking, however, does not imply disregard for the fact that such elements (including, for example, the direction and editing) can add further layers to the meaning conveyed by the plots and dialogue. The article addresses primarily the levels of 'discourse' and
} 
point for refugees, as a gathering ground for spies, and as a safe haven from European war and oppression. The article will then briefly compare this portrayal with that of Spain, where a similar political regime was in place. It will conclude that the combination of Hollywood's formulaic narratives and Washington's propaganda strategy resulted in a depiction of Portugal that was patronising yet mostly benevolent, romanticising local living conditions and dissociating the Salazar dictatorship from its fascist origins and practices.

The Portuguese authorities were not directly involved in the productions under analysis. António de Oliveira Salazar notoriously disliked North American culture and so did several figures of his regime. Despising hedonistic consumerism and the United States' connotation with $19^{\text {th }}$ century liberalism, Salazar saw in the USA's conception of modernity a clash with his ruralist, Catholic values and looked on the Americans 'as a barbaric people illuminated not by God but by electric light'. ${ }^{7}$ The dictatorship had its own dynamic cultural production program under the direction of António Ferro, head of the Office of Propaganda (Secretariado da Propaganda Nacional) and a key proponent of the regime's ideology. While unfavourably comparing the USA's culture and society to those of Portugal, however, Ferro did prove keen to shape American views towards his country. Most prominently, he organised the Pavilion of Portugal in the 1939-40 New York World's Fair, which was likely viewed by some of the filmmakers who later worked on Portugal-themed productions. ${ }^{8}$ Moreover, António Ferro was an outspoken enthusiast

\footnotetext{
'design', two of the four strata in which meanings are dominantly made (the others being 'production' and 'distribution'), as defined by G. Kress, T. van Leeuwen, Multimodal Discourse: the modes and media of contemporary communication (London 2001), 4-8.

7 D. Eccles, By Safe Hand: Letters of Sybil \& David Eccles 1939-42 (London 1983), 292. On this topic, see L.R. Torgal, Estados Novos, Estado Novo: ensaios de história política e cultural, vol.2 (Coimbra 2009), 55260; J.F. Antunes, Roosevelt, Churchill e Salazar: a luta pelos Açores, 1941-1945 (Alfragide 1995), 33-7; J.F. Antunes, 'Kennedy, Portugal, and the Azores Base, 1961', in D. Brinkley and R.T. Griffiths (eds), John F. Kennedy and Europe (Baton Rouge 1999), 149. Although Salazar displayed some interest in cinema, this interest was directed at Portuguese films, not at foreign productions (L.R. Torgal, 'Introdução', in L.R. Torgal (ed.), O Cinema sob o Olhar de Salazar (Lisbon 2000), 34-5). For a virulent indictment of film entertainment, particularly American, by the Catholic intellectual circles, see J.A.C. Neves, $O$ Cinema e o Seu Sentido Cristão do Amor e da Família (Lisbon 1944) and J.A.C. Neves, Cinema e Cultura (Coimbra 1946). ${ }^{8}$ R.C. Martins, Exposições Universais: Nova lorque 1939 (Lisbon 1996), 64-70; 'National Exhibit Dedicated by Portuguese Envoy', The New York Times (9 May 1939). For the Pavilion's brochure, see http://www.1939nyworldsfair.com/portugal/portugal.aspx [accessed 20.08.2015]. Portugal also secured a pavilion at the 1939-40 Golden Gate International Exposition, in San Francisco (P.L.C. Silveira, 'A Casa de Portugal na Feira', Jornal Português (4 October 1940), in Arquivo Histórico-Diplomático do Ministério dos Negócios Estrangeiros, DM/1. LEGS.EMBS/Washington/68626, M52). The largest scale attempt to project the dictatorship's symbols and ideological narrative regarding the history of Portugal was the Portuguese World Exhibition, which opened in Lisbon in June 1940, but its intended international impact was severely
} 
of the enthralling potential of cinema in general and Hollywood in particular. ${ }^{9}$ Ferro argued that cinema was the 'main weapon' allowing 'Americanism' to gain ground over both fascism and communism among younger generations, concluding that it was 'already too late for us to fully defend ourselves (I mean all Europeans) from the great offensive of images that has occupied, if not the soul, the senses of the youth of our time.' Acknowledging that the Portuguese film industry was not able to compete on the same level, in the early 1940s he proposed to Salazar taking advantage of 'the very weapon' that 'battles our civilisation'. Ferro planned an ambitious lobbying strategy with the aim of making Portugal 'fashionable' among Hollywood studios, thus harnessing the power of their products to promote the regime's image of the country. ${ }^{10}$ While Salazar did not follow through on Ferro's plan, the wartime context - as this article will demonstrate did secure Portugal a fair amount of publicity, as this country briefly became a recurrent feature of North American motion pictures.

Even without active Portuguese interference, what each movie said about Portugal resulted from different, overlapping concerns informing its production process. These films were the outcome of a long chain of creative decisions involving multiple screenwriters, producers, directors, actors, and crews. Because some $40 \%$ of Hollywood's revenues were generated abroad, the concerns of studios' legal and distribution branches about how films would play overseas had to be taken into great account as well. ${ }^{11}$ This included (but it was hardly exclusive to) Portugal, which in 1942, with most of Europe closed to American movies, became one of the few continental countries getting shipments. ${ }^{12}$ Major distributors like Metro-Goldwyn-Mayer (MGM), Paramount, $20^{\text {th }}$ Century-Fox, and RKO had their own representatives in Portugal, which by 1944 housed

overshadowed by the German advance on France taking place at the time (N. Lochery, Lisbon: War in the Shadows of the City of Light, 1939-1945 (New York 2011), 32-5).

${ }_{9}^{9}$ A.P. Pita, 'Temas e Figuras do Ensaísmo Cinematográfico', in Torgal, Cinema sob o Olhar de Salazar, 437; O. Raimundo, António Ferro: O Inventor do Salazarismo (Alfragide 2015), 107-11; Torgal, Estados Novos, Estado Novo, 58-9, 178-9.

${ }^{10}$ Portuguese National Archives at Torre to Tombo [TT], AOS, Cx.662, PC-12E, Plano de uma campanha de lusitanidade em toda a América, em especial no Brasil, 14-17. For the background of Ferro's plan, see C. Ribeiro, 'António Ferro e a projeção atlântica de Portugal através do cinema', Aniki: Portuguese Journal of the Moving Image, 1:2 (2014), 151-75.

$11 \mathrm{~J}$. Trumpbour, Selling Hollywood to the World: U.S. and European Struggles for Mastery of the Global Film Industry, 1920-1950 (Cambridge 2002), 91; R.L. McLaughlin, S.E. Parry, We'll Always Have the Movies: American Cinema During World War II, (Lexington 2006), 17.

12 The others were Finland, Spain, Sweden, Switzerland, and Turkey. - Segrave, American Films Abroad, 128. 
approximately 285 theatres available for American films. ${ }^{13}$ Likewise, the industry's trade organisation, the Motion Picture Producers and Distributors of America (MPPDA), besides enforcing its own morally-minded censorship through the Production Code Administration (PCA), advised filmmakers on the tastes and prejudices of foreign censors and audiences. Traditionally the MPPDA sought to prevent movies from giving offence to any country with a profitable market by favouring a conservative policy of 'pure entertainment' over productions that dealt with controversial international events. ${ }^{14}$

Hollywood also came under pressure by forces outside the industry. In his address to Congress one month after the USA's entry into the war - following the Japanese attack on Pearl Harbour in December 1941 - President Franklin D. Roosevelt stressed the need for public information and understanding on different aspects of the conflict. ${ }^{15} \mathrm{He}$ later tasked the Office of War Information (OWI) with coordinating propaganda at home and abroad. This government body, with a markedly progressive-leaning staff, sought to present the war as an ideology-driven struggle between fascism and democracy, the United States fighting for a new world based on the Four Freedoms - freedom of speech and religion, and freedom from want and fear. The OWI's Bureau of Motion Pictures tried, not always successfully, to shape films' content through recommendations to the studios and to the Office of Censorship, in charge of restricting export rights. In the final years of the war, the Office of Censorship followed most of the OWI's recommendations, which thus became increasingly influential, as producers had little financial interest in pictures they knew in advance would be limited to domestic exhibition. Indeed, it was precisely the awareness that Hollywood drew an average of 80 million paid admissions per week from foreign audiences that led the bureau to emphasise cinema's impact on the USA's reputation abroad. ${ }^{16}$

Notably, the fact that the overwhelming majority of films playing in Portugal were North American enabled some soft power in this country. ${ }^{17}$ By threatening to withdraw

\footnotetext{
13 'Potential World Market 60,985 Houses, U.S. Says', Motion Picture Herald (16 September 1944); 'Portuguese 1944 Admissions Total Near 18,500,000', Motion Picture Herald (19 January 1946).

${ }^{14}$ M. Glancy, When Hollywood Loved Britain: The Hollywood 'British' Film 1939-1945 (Manchester 1999), 38. For a look at the PCA's accommodating attitude towards European fascism in the thirties, see T. Doherty, Hollywood and Hitler, 1933-1939 (New York 2013). For the PCA's work during World War II, see T. Doherty, Projections of War: Hollywood, American Culture, and World War II (New York 1999 [Revised and updated edition]), 38-59.

${ }^{15}$ D.B. Jones, 'The Hollywood War Film: 1942-1944', Hollywood Quarterly, 1:1 (1945), 1-2.

${ }^{16}$ C.R. Koppes, G.D. Black, 'What to Show the World: The Office of War Information and Hollywood, 19421945', The Journal of American History, 64:1 (1977), 87-105.

17 United Press correspondent Bob Musel emphasised this link in early 1943, while describing Portugal as 'a nation whose choice in films is more than 95\% American' ('Lisbon chooses 95\% U.S. Films, Best Goodwill
} 
popular fiction films, in 1943 American distributors managed to push reluctant Portuguese cinemas to exhibit pro-Allies documentaries and the USA's commercial attaché managed to influence the election of the president of Portugal's Film Distributors Guild. ${ }^{18}$ Washington placed great value in its relations with the Portuguese dictatorship, whose neutrality status did not prevent instances of collaboration with the belligerent nations. Of crucial importance were the highly strategic bases in the Portuguese archipelagos of Cape Verde and the Azores. Anglo-American negotiations with Salazar - which also sought the embargo of Portuguese wolfram to Germany - eventually led to agreements granting the United Kingdom (UK) and the USA access to the Azores, signed in August 1943 and November 1944, respectively. ${ }^{19}$ With these negotiations in mind, the OWI feared the possibility of Hollywood undermining the cooperative attitude of the Salazar regime, arguing that in 'view of the strategic importance of the delicate balance maintained by Portugal, an unfavorable portrayal which would in any way offend the Portuguese is apt to have international ramifications'. ${ }^{20}$

While recognising that there was no clear, unified vision behind the films under analysis, Portuguese depictions can still be framed within a wider historical context. Approximately a third of the 1,313 motion pictures released in the United States during the three years following Pearl Harbour directly concerned some aspect of the Second World War. ${ }^{21}$ In fact, even before the USA entered the war, filmmakers had already blazed the trail with some 50 movies appealing, overtly or through blatant metaphors, to anti-Nazi sentiment, military preparedness, and solidarity with the UK and its allies. ${ }^{22}$ Meanwhile, under the economic boom of the early 1940s, 90 million newly prosperous

\footnotetext{
Force in Seething Capital', Variety (3 February 1943)). According to Variety, this tendency also applied to the Portuguese colony of Angola, with about $90 \%$ of the films playing there at the time being US productions ('Around the World', Variety (24 May 1943)). While these claims may be exaggerated, all sources point to some degree of Hollywood dominance. For example, official figures compiled by the Portuguese government indicated that $65 \%$ of the 257 pictures released in Lisbon in 1944 came from the USA ('Portuguese 1944 Admissions Total Near 18,500,000', Motion Picture Herald (19 January 1946)). For the concept of 'soft power', including Hollywood's role in the USA's international influence, see J. Nye, Bound to Lead: The Changing Nature of American Power (New York 1990).

${ }^{18}$ A.J. Telo, Propaganda e Guerra Secreta em Portugal (1939-45) (Lisbon 1990), 80-2.

${ }^{19}$ L. Andrade, 'The Azores and the Second World War', and L.N. Rodrigues, 'Franklin D. Roosevelt and the Azores in World War II', both in L.N. Rodrigues (ed.), Franklin Roosevelt and the Azores During the Two World Wars (Ponta Delgada 2008), 337-50 and 351-64; Teixeira, 'Caught on the Periphery'; Antunes, Roosevelt, Churchill e Salazar.

${ }^{20}$ US National Archives and Records Administration [NARA], College Park, MD, Records of the OWI, Record Group 208, NC148567-4742245, Box 3526, Storm Over Lisbon, Letter from William S. Cunningham to William Gahagan, 31.03.1944.

${ }^{21}$ Jones, 'Hollywood War Film', 2-3.

22 B.F. Dick, The Star-Spangled Screen: The American World War II Film (Lexington 1996), 93-7.
} 
Americans went to the movies each week. Contrary to news reports about ongoing events, fiction films provided complete narratives about the war while enjoying greater popularity than other fictionalising media, like radio, theatre, and comics. Hollywood was at the centre of a pop-culture-wide 'emphasis by repetition', translating abstract elements of the conflict into a sense of specific knowledge and replicating ideas about the war through recurrent character types, plots, symbols, and rhetoric. Movies offered ways to understand how the war was being fought, its significance for Americans and their role in the conflict, why audiences should hate the USA's enemies and support its allies, and what outcome to expect. ${ }^{23}$ As part of this process they also offered, both deliberately and incidentally, recurrent ways to regard Portugal and its regime.

One of Portugal's most appealing facets for North American film fiction was the refugee crisis that took place in and around Lisbon, starting in the summer of 1940. Thousands of European refugees, including several members of the film industry, passed by the Portuguese capital, often facing complicated lodging and economic challenges while waiting for travelling visas. Many aimed to leave for the USA, either through the expensive Pan American Clipper that departed regularly from the Cabo Ruivo terminal to New York City or through alternative, not always legal, transportation. ${ }^{24}$ This generated a perceptible contact point between the two countries, whose dramatic potential Hollywood exploited to varying degrees.

The first American motion picture to address this situation was the 21-minute long Forbidden Passage, released in February 1941 as part of the long-running Crime Does Not Pay series of shorts produced by MGM. ${ }^{25}$ The series, personally endorsed by the Director of the Federal Bureau of Investigation (FBI), J. Edgar Hoover, aimed to discourage transgression and to promote respect for modern equipped crime-fighting authorities by telling fictionalised tales in which lawbreakers were swiftly punished. ${ }^{26}$ In Forbidden Passage, a refugee in Lisbon, impatient about joining his wife and children in the United States, resorted to a smuggling network and ended up drowning when the smugglers threw him overboard during a raid by the USA's immigration services (the

\footnotetext{
${ }^{23}$ For a more developed discussion of each of these aspects, see McLaughlin/Parry, We'll Always Have the Movies, 6-14.

${ }^{24}$ I. Pimentel, Judeus em Portugal durante a II Guerra Mundial (Lisbon 2006); R. Weber, The Lisbon Route: Entry and Escape in Nazi Europe, (Lanham 2011).

${ }^{25}$ A Crime Does Not Pay Subject: Forbidden Passage, Dir. Fred Zinnemann, MGM, 1941.

${ }^{26}$ D. Kehr, 'Justice Served, Justice Blurred', The New York Times (20 July 2012).
} 
agency to whom the movie was dedicated). While packed with suspense and pathos, ${ }^{27}$ this short film remained a functional message picture, one with the explicit central message that American citizens should refrain from helping their relatives enter the USA by illegal means. Unlike its competitors, MGM - the only major studio headed by a Republican, Louis B. Mayer - was not yet keen to back Roosevelt's internationalist foreign policy. ${ }^{28}$ Made almost a year before the United States joined the war, Forbidden Passage's isolationism shone through: its portrayal of refugees seeking to reach America through Portugal, although not entirely devoid of compassion, lacked vital context - with no clear references to the war or to the Jewish persecution in Europe - and it essentially presented the issue as a threat to the law.

Forbidden Passage's take on this subject was the exception rather than the rule, particularly once the USA joined the war, so Portugal gradually became associated, in North American cinema, with a more unambiguously sympathetic view of the refugees' plight. After a few frustrated attempts to develop productions about the Clipper flights, ${ }^{29}$ Lisbon's role in the international escape route gained major visibility with a highly popular movie that did not feature a single scene set in Portugal: Casablanca (1942). ${ }^{30}$ Set in the film's titular city, full of expatriates and under colonial rule of the collaborationist Vichy regime, Casablanca invited its audience to root for heroic refugees to obtain passage to Portugal, at all costs. Throughout the film, Lisbon was constantly

\footnotetext{
${ }^{27}$ Forbidden Passage was nominated for the Oscar of Best Live Action Short Film, Two Reel [The 14th Academy Awards, available at http://www.oscars.org/oscars/ceremonies/1942 accessed 06.08.2015]. ${ }_{28}^{28}$ M.T. Bennett, One World, Big Screen: Hollywood, the Allies, and World War II (Chapel Hill 2012), 9-10.

${ }^{29}$ An executive at Warner Bros. urged journalist Eric Sevareid to write a story called Lisbon Clipper. Sevareid drafted a plot sketch for a thriller-romance involving an American vice-consul in Lisbon and a Czech actress running from the Gestapo, but it is unclear whether he submitted this sketch (Weber, Lisbon Route, 90). In 1941 The New York Times reported twice about a Warner production called Lisbon Clipper, the first time stating that it would be 'dealing with the British secret service' and would be written by Maurice Hanline and Jesse Lasky Jr, and the second time stating that Bert Granet would prepare the script from a yarn by Gordon Wellesley and Bail Woon ('Screen News Here and in Hollywood', The New York Times (17 September 1941 and 3 October 1941)). MGM began developing, yet did not complete, Episode in Lisbon, assigned to screenwriters Howard Emmett Rogers and Albert Mannheimer, and described in the magazine Movie-Radio Guide as 'a modern romance about a gal who wants to get to America on a Clipper plane, and a boy who has one of those tickets which are so hard to get these days...' ('This Week in Hollywood', Movie-Radio Guide (23 November 1940); see also 'O novo filme de Robert Taylor para a MG-M passa-se em Lisboa!', Animatógrafo (1 March 1941); 'Screen News Here and in Hollywood', The New York Times (13 March 1941); S.M. Shearer, Beautiful: The Life of Hedy Lamarr (New York 2010), 121, 131). In early 1941, the small production company Colonnades Pictures announced a feature-length drama called Last Clipper from Lisbon, based on an original story by Frank Clemente and dealing 'with Hitler's theoretical invasion of Portugal a year hence' ('Big Productions Outlined By Colonnades Pictures', The Miami Daily News (25 March 1941); 'Hollywood Veteran Stakes All On Movie-Making Here', The Miami Daily News (29 March 1941); 'Colonnades Studios Gets Second Recording Unit', The Film Daily (24 April 1941)).

${ }^{30}$ Casablanca, Dir. Michael Curtiz, Warner Bros, 1942.
} 
referred to as a coveted destination, unquestionable first stage in the path to the USA. Such an image was reinforced by Journey for Margaret (1942), whose final act focused on the efforts of an American journalist in London to include two children, orphaned by German bombings, in the limited flights connecting the UK to Portugal, in order to then take them to the United States. ${ }^{31}$ The Portuguese stepping stone also served as a plot point in the home front thriller The Fallen Sparrow (1943), where the hero - not a refugee, but a veteran of the Spanish Civil War - had hidden a flag in Lisbon on his way to the USA and the dénouement concerned a flight back to Portugal to retrieve it. ${ }^{32}$ Voice in the Wind (1944) readdressed the perils of illegal immigration with the saga of a Czech pianist who tried to reach the United States by boarding a smuggling ship in Lisbon and ended up in Guadalupe Island. ${ }^{33}$

If in these films the Portuguese waypoint was key to the plot yet barely visible on screen, three 1944 productions sought to fully capture the atmosphere of a country where people of various nations struggled to get passage to the USA, in an attempt to apply to Portugal Casablanca's successful dramatic formula. ${ }^{34}$ Storm Over Lisbon-mostly set in Estoril, just outside Lisbon - featured as a leading character a Czech dancer named Maritza who seemingly made a deal with an international criminal in order to obtain a much coveted seat in the Clipper to New York. ${ }^{35}$ The Conspirators, which revolved around a Dutch resistance hero in transit to London via Portugal, also addressed the refugees' situation, although this remained marginal to the plot, serving essentially as a colourful background detail. For example, the protagonist introduced Lisbon by calling it 'the gateway to freedom' and later an elaborate shot across a café showed various men

\footnotetext{
31 Journey for Margaret, Dir. W.S. Van Dyke, MGM, 1942.

32 The Fallen Sparrow, Dir. Richard Wallace, RKO, 1943.

${ }^{33}$ Voice in the Wind, Dir. Arthur Ripley, United Artists, 1944.

${ }^{34}$ As early as January 1943, Warner Bros. had bought an original Lisbon-set story titled Passage to Lisbon with the intent of producing a movie that would feel like a follow-up to Casablanca, starring much of the same cast ("'Casablanca" Follow Up Now Planned', The Milwaukee Sentinel (5 February 1943); 'Studios Buy 55 Stories in January, February', Motion Picture Herald (27 March 1943)). Likewise, behind the studio's decision to buy the rights to The Conspirators, in April 1943, was the wish to reunite at least the male members of Casablanca's cast, including Humphrey Bogart, Paul Henreid, and Sydney Greenstreet ('Screen News Here and in Hollywood', The New York Times (24 April 1943); Shearer, Beautiful, 183). Warner itself encouraged the comparison between The Conspirators and Casablanca in prepared press items such as "The Conspirators," Dramatic Love Story, Opens At Strand' and 'It Thrills- It Excites- It's a New "Casablanca"' (British Film Institute, Reuben Library, The Conspirators Pressbook). Reviews for Storm Over Lisbon also recurrently picked up on this trend (AMPAS, General Collection, Storm Over Lisbon, 'Excellent Credit for Geo. Sherman', Hollywood Reporter (28 August 1944), and 'Storm Over Lisbon', Independent (02 September 1944)).

${ }^{35}$ Storm Over Lisbon, Dir. George Sherman, Republic Pictures, 1944.
} 
and women discussing, in different languages, strategies to move on from Portugal. ${ }^{36}$ Finally, The Hairy Ape, an adaptation of Eugene O'Neill's 1922 play with the same title, went quite out of its way to incorporate the Portuguese setting. ${ }^{37}$ The original play had nothing to do with refugees - it told the story of a brutish stoker in an ocean liner who at one point was confronted by Mildred, a rich passenger on her way to Europe. ${ }^{38}$ In the Hollywood version, Mildred was now returning from Portugal where she had gone to help out with the refugee crisis, the ocean liner now a freighter tasked with transporting refugees from Lisbon to New York. The filmmakers added a whole first act set in the Portuguese capital, which introduced the main characters before they boarded the ship. Although the movie briefly referenced the elite exile community, it devoted more screen time to vulnerable refugees in transit from Portugal, whom a minor character described as 'just poor people trying to get where they'll be safe and they'll be free', that is, to America. ${ }^{39}$ This point was emphasised by a released press story about an extra breaking down in tears during the shoot, because she herself was a French refugee who had 'reached Lisbon after great difficulty' and had waited for two months with 'the constant fear in her that she wouldn't get out and might be forced to return to France'. ${ }^{40}$

While these films cemented the image of Portugal as a cosmopolitan waiting room for the Promised Land, almost none of them engaged with the role of the local authorities in dealing with the refugees. The only Portuguese characters in Forbidden Passage were connected to the smuggling ring, namely an employee of the USA Consulate in Lisbon and his unseen accomplice. In Voice in the Wind, although the contraband ship operated out of a Lisbon harbour, the locals were not involved - in fact, an Italian smuggler even sadistically beat up a Portuguese woman for disrespecting him. Policemen supervised the embarkation of the freighter in The Hairy Ape and the Clipper in Storm Over Lisbon, but were notoriously absent during a shootout at the Cabo Ruivo terminal in the latter film. Because of this apparent laxity and the longer screen time devoted to characters who sounded anxious to leave Portugal, Storm Over Lisbon treaded on uncertain ground, but the production was ultimately validated by the Portuguese Consulate in San Francisco, if not enthusiastically so. Having heard that the planned film dealt unfavourably with

\footnotetext{
${ }^{36}$ The Conspirators, 02:42 and 08:36-55.

37 The Hairy Ape, Dir. Alfred Santell, United Artists, 1944.

${ }^{38}$ Eugene O'Neill, The Hairy Ape, and other plays (London 1923).

${ }^{39}$ The Hairy Ape, 13:34-7.

${ }^{40}$ Wisconsin Center for Film and Theater Research [WCFTR], United Artists Collection, Series 1.4, Micro 448, Reel 14, The Hairy Ape Pressbook, 'Real Refugee Tears'.
} 
Portugal's treatment of refugees, in March 1944 the consul contacted the OWI, which arranged a screening for Henrique Medina, a representative of the Consulate. Medina 'saw no value whatsoever in the film from the standpoint of the Portuguese, but agreed that it could do little harm'. ${ }^{41}$ Finally, in The Conspirators, the one production to actually depict the authorities' interaction with the refugees, the Portuguese were portrayed as competent yet compassionate. Early in the film, a sequence at the airport showed passengers arriving in a flight from Madrid and going through strict customs and immigration control. A police officer, Captain Pereira, was shown to have a tight grasp of the passenger list and to spot inconsistencies in the protagonist's passport, such as the absence of German border stamps - which suggested he had illegally escaped from Nazioccupied Holland - yet nevertheless approved a visa for 36 hours with a light warning about respecting Portugal's neutrality while in town.

Like Pereira, Hollywood was at least as interested in incoming spies as it was in refugees. To a great degree, North American World War II movies were merely adapting established narrative formulas to themes related to the ongoing conflict, so Hollywood launched a spy film cycle, like it had done in the First World War. Espionage was an element of the conflict that held perennial fascination for the public and was relatively easy to write about, spy stories often being speculative and essentially revolving around a gimmicky plot device sought after by the main characters. ${ }^{42}$ The free circulation of belligerent nationals in Portugal allowed screenwriters to elaborate plots around multiple international agents. The fact that Lisbon was also the embarkation point for the USA further increased story possibilities, a combination which was taken advantage of in the 1941 thriller International Lady, where the titular spy stopped in Lisbon to get instructions from her underground partners while on the way to the United States. ${ }^{43}$ More than a convenient subject for filmmakers, the choice of the Portuguese capital was grounded in the actually quite widespread level of espionage taking place in Portugal at the time. This was underlined by The House on $92^{\text {nd }}$ Street, an influential semidocumentary thriller released shortly after the end of the war, which according to its written prologue adapted actual cases from the espionage files of the FBI and was

\footnotetext{
41 NARA, College Park, MD, Records of the OWI, Record Group 208, NC148567-4742245, Box 3526, Storm Over Lisbon, Letter from Bill Cunningham to W.R. Rothacker, 22.05.1944.

42 Dick, Star-Spangled Screen, 97.

${ }^{43}$ International Lady, Dir. Tim Whelan, United Artists, 1941.
} 
produced with that organisation's complete cooperation. When, at one point in the film, an American double-agent infiltrating Nazi intelligence passed out information to the FBI via Lisbon, the narrator sternly described the city as the "communication center for international espionage'. ${ }^{44}$

Spy craft's reliance on subterfuge made it an obvious fit not only for thrillers, but also for the popular genre of the romantic comedy of errors. Such was the case with One Night in Lisbon, ${ }^{45}$ which used John Van Druten's 1931 play There's Always Juliet as basis for the story, with various changes made by screenwriter Virginia Van Upp. While in the play the London-based protagonists talked about a trip to Paris, in the final third of the film they actually travelled to another European capital, Lisbon, which allowed for an extended screwball sequence in a Portuguese hotel crawling with German spies. ${ }^{46}$ The Lady Has Plans went further, taking place almost entirely in Portugal and hinging the plot on a case of mistaken identity between freelance spy Rita Lenox, who had secret plans for a torpedo tattooed to her body, and reporter Sidney Royce, who was consequently approached by agents of different nations trying to look at her naked back. ${ }^{47}$ The rationale for combining espionage and romantic comedy in Portugal came through in Leo Birinski's original story treatment for The Lady Has Plans. In a passage that did not make it to the final script, Sidney's character (then called Corinne) explained to her editors that Lisbon's status as 'the greatest espionage center on earth - chuck full of cosmopolitan adventures and international busybodies' made it a perfect setting for spy narratives featuring women, which could help lure in a female audience:

\begin{abstract}
Women readers are sick of monotonous bombing and torpedoing! There has never been a scrap in history so short on feminine appeal. No wonder they don't like this mechanized war! But there is one part that is not mechanized - the spying! At least not the woman's end of it. [...] There are glamorous spies galore. Women want to read about them - and men, too. ${ }^{48}$
\end{abstract}

\footnotetext{
44 The House on $92^{\text {nd }}$ Street, Dir. Henry Hathaway, $20^{\text {th }}$ Century-Fox, 1945, 17:20-28. For more on the circulation of spies in Portugal during World War II, see Telo, Propaganda e Guerra Secreta, 83-176; I. Pimentel, Espiões em Portugal Durante a II Guerra Mundial (Lisbon 2013); Lochery, Lisbon, 125-54; R. Araújo, O diário secreto que Salazar não leu (Cruz Quebrada 2008).

45 One Night in Lisbon, Dir. Edward H. Griffith, Paramount Pictures, 1941.

${ }^{46}$ AMPAS, General Collection, One Night in Lisbon, program of press preview.

${ }^{47}$ The Lady Has Plans, Dir. Sidney Lanfield, Paramount Pictures, 1942.

${ }^{48}$ AMPAS, Paramount Pictures Scripts, 00952, Original story, 'The Palace of a Thousand Lies', 27.03.1941, pp.5-6.
} 
Whether primarily motivated by ideology or by the studios' desire to increase their profit margin, the choice of incorporating current affairs into the plots made these films inherently political. By its very nature, spy fiction tends to engage with international politics, reflecting antagonisms among major world powers at particular historical junctures, the case of World War II being no exception. ${ }^{49}$ For example, the promotion of Anglo-American cooperation in films made before Pearl Harbour could hardly be decoupled from its war-related implications. ${ }^{50}$ By presenting a romance between an English woman (volunteering as a driver for the British Ministry of War) and a Texan pilot (supplying American bombers to the UK) and later showing the pilot joining forces with his British love rival (a Navy officer) against German agents in Portugal, even a romantic comedy like One Night in Lisbon was unequivocally propagandistic, much as the intelligentsia criticised its light approach to the subject matter. ${ }^{51}$ What inescapably politicised these films was the fact that through their simple heroes-versus-villains formula they were delineating who the real life heroes and villains were considered to be in the actual conflict. The same applies to spy movies made after the USA joined the war, most of which continued to narrow down the threat to agents of fascist belligerent nations,${ }^{52}$ despite the OWI's appeals for the main enemy to be identified as fascism itself and fascist supporters anywhere rather than specifically the Axis leaderships or the Axisled peoples. ${ }^{53}$

By depicting the Portuguese authorities in this context, Hollywood was therefore assigning them a role in the simplistic confrontation between the heroic Allies (including the anti-Nazi resistance) and the villainous forces of the Axis. Specifically, Portugal appeared as a neutral nation, but one whose approach to neutrality did not stand in the

\footnotetext{
${ }^{49}$ R.W. Gregg, International Relations on Film (Boulder, CO 1998), 99-107.

${ }^{50}$ International Lady, which showed the FBI cooperating with the Scotland Yard to put down the sabotage of American bombing aircraft being ferried to the UK, became newsworthy because it was previewed just as a subcommittee of the USA Senate began an investigation into Hollywood's pro-British 'war mongering' (AMPAS, General Collection, International Lady, Look (11 April 1941)). For an extended discussion of proBritish cinema during this period, see Glancy, When Hollywood Loved Britain.

${ }^{51}$ Film critic John Mosher remarked that to 'no one today, I am sure, does the idea of Lisbon mean a bedroom farce of the old-fashioned Avery Hopwood school, tinctured with moderate Minsky humors, maudlin, befuddled, and childishly ribald - which is exactly what this movie turns out to be' ('The Current Cinema: The Lower Depths', The New Yorker (14 June 1941)). The film organisation National Board of Review, although praising the need for propaganda, argued that on that front One Night in Lisbon 'would make any American audience howl with amusement, if not derision, at the puerile stuff that is to inspire them to great deeds and large expense' (AMPAS, General Collection, One Night in Lisbon, 'The Quality of Propaganda', National Board of Review Magazine, May 1941).

52 Jones, 'The Hollywood War Film', 4-6.

${ }^{53}$ Koppes/Black, 'What to Show the World', 91-2.
} 
way of the interests of the Allies. This perspective was still implicit in The Lady Has Plans, where the Lisbon police conveniently saved the American heroes by arresting the German foes, who were forging Portuguese passports. Storm Over Lisbon finished with a similar deus ex machina, as the protagonists were rescued by the intervention of Portuguese secret agents, including a likable trio who - disguised as street musicians had been providing some of the movie's soundtrack and comic relief. This film, however, presented Portugal's help as deliberate and high-level. In the story, Lisbon's Ministry of Justice recruited the dancer Maritza to help dismantle an espionage ring that, according to a ministry official, was 'watched and frowned upon by the Allied governments'. ${ }^{4}$ The OWI did nevertheless ensure Portugal's neutral status was not fully disrespected by convincing director George Sherman to cut a line in which Deresco, the villain, bragged about his willingness to make deals with any country by quipping: 'In neutral Lisbon I think I'm the only one who is truly neutral.' 55 Sherman - who according to the OWI's Los Angeles Overseas Bureau was 'most anxious to avoid giving any offense to the Portuguese ${ }^{56}$ - also changed another line at the request of Henrique Medina, who wanted to make sure it could not be inferred from the film that official Portuguese sentiment was actually pro-Allied rather than neutral. ${ }^{57}$

The case of The Conspirators is less straightforward. This film told the story of Vincent Van Der Lyn, a Dutch member of the anti-Nazi underground who during a stopover in Lisbon found romance, was framed for murder, and exposed a German double agent. Among the many similarities to Casablanca, ${ }^{58}$ The Conspirators featured a local police officer who ended up helping the resistance: although professing his duty to preserve Portugal's neutrality throughout the movie, Captain Pereira was ultimately revealed to harbour anti-Nazi feelings due to a sister in England and a brother-in-law who had been tortured and killed in Norway. Pereira therefore intentionally allowed the hero

\footnotetext{
${ }^{54}$ Storm Over Lisbon, 41:22-35.

55 NARA, College Park, MD, Records of the OWI, Record Group 208, NC148567-4742245, Box 3526, Storm Over Lisbon, Cunningham to Gahagan, 31.03.1944.

56 Ibid.

57 NARA, College Park, MD, Records of the OWI, Record Group 208, NC148567-4742245, Box 3526, Storm Over Lisbon, Cunningham to Rothacker, 22.05.1944.

58 They were similarly themed romantic dramas / political thrillers produced by Warner Bros. where Paul Henreid starred as a hero of the resistance. Both started out as projects led by producer Hal B. Wallis and both had expressionist photography by Arthur Edeson, as well as prominent supporting roles by Peter Lorre and Sidney Greenstreet. Despite the effort to mimic Casablanca's success, however, The Conspirators was marred by a convoluted production process, including a battle of egos between producers. - R. Barton, Hedy Lamarr: The Most Beautiful Woman in Film (Lexington, 2010), 140-4; J. Negulesco, Things I did and things I think I did (New York, 1984), 121-3; Shearer, Beautiful, 182-6, 192-3.
} 
to escape from the law and even saved his life by shooting down the double agent who was about to kill Vincent. Pereira's actions were not treated as official policy, but an early scene established that his choices mirrored the regime's collaborationist attitude towards the Allies: when German agent Otto Lutzge questioned whether Portugal's alleged neutral status existed 'despite the British in the Azores' (i.e. in the Azores airbase), Pereira answered 'And the Cape Verde islands, in spite of that too', leading Lutzge to comment: 'Such neutrality is one-sided, Captain Pereira. Your sympathies are obvious. ${ }^{59}$ This character's arc was particularly remarkable because he was the most fleshed out and relatable Portuguese in the movie, downplaying his 'otherness' - unlike many of the extras and minor characters (as discussed below), Pereira lacked a thick accent, exaggerated mannerisms, or clothes that would look out-of-place on an American counterpart. In a comparatively less prominent role, Pereira's superior, Colonel Almeida, was also shrewd and articulate but stuck more closely to his professional obligations. The OWI remarked that in one scene Almeida was 'suspiciously conspicuous at a party at the German Embassy', ${ }^{60}$ although the story treatment indicates that the character's behaviour was not meant to convey any pro-Axis leaning:

For the character of the chief of police, Almeida, perhaps one might use the excellent description of da Veda in [Guy Endore's unproduced screenplay] "The Gamblers", the Portuguese aristocrat who is dirtying his hands with police affairs because he must try to help his country with dignity and honor through a difficult period in her history. His heart is all with England - the established policy of Portugal for centuries - but he wants to walk the tight-wire of neutrality until it will be safe for his country to go ahead. ${ }^{61}$

Depictions of the Portuguese authorities can indeed be read through different sensibilities. On the one hand, these films showed those authorities as unable to prevent Lisbon from becoming a centre of German intrigue. The OWI therefore ruled The

\footnotetext{
59 The Conspirators, 04:22-30.

60 NARA, College Park, MD, Records of the OWI, Record Group 208, NC148567-4741004, Box 3514, The Conspirators, Dispatch from the OWI's L.A. Overseas Bureau, Motion Picture Division, 07.10.1944.

${ }^{61}$ WCFTR, United Artists Collection, Series 1.2, Box 74, Folder 8, Sketch of action for "The Conspirators" by Frederick Faust, 09.04.1943, p.5. The Gamblers told the story of three Nazi agents who travelled to Lisbon on a mission to convince Portugal's business elites to build submarine bases in the Atlantic. Count da Veda was a Portuguese nobleman who refused to cooperate with the Nazis, invoking the centuries-old Anglo-Portuguese Alliance. - University of California, Los Angeles, Charles E. Young Research Library, S. Guy Endore papers, Box 42, "The Gamblers" First draft continuity.
} 
Conspirators as unsuitable for distribution in Portugal, 'where audiences might resent the reflection on their neutrality'. This agency's reviewers argued that Pereira's turnabout and the fact that in one sequence Vincent singlehandedly contrived his escape from a Lisbon jail would likewise suggest 'some laxity in police efficiency' ${ }^{62}$ Similarly, the OWI lamented that Storm Over Lisbon was 'full of violence and intrigue, which by implication could reflect on Portuguese authorities', as well as the fact that the threatened American hero hid out in an old farmhouse 'rather than trust himself to the authorities for protection' ${ }^{63}$ One of Henrique Medina's few objections concerned a dialogue early in the movie that gave the impression that Lisbon might be 'full of cutthroats and mysterious evil-doings' ${ }^{64}$ This did not prevent Storm Over Lisbon from airing in its titular city indeed, it was one of the few movies discussed in this article to have done so during the war. ${ }^{65}$ Yet Portuguese censors were not insensitive to the implications of Hollywood's portrayal of Lisbon, having cut out the line in The House on $92^{\text {nd }}$ Street which described the Portuguese capital as the 'communication center for international espionage'. 66

On the other hand, Hollywood avoided treating Portuguese institutions as seriously incompetent or their motivations as unkind. Maritza's status as an undercover agent of the secret police, the Portuguese authorities' awareness of the Deresco spy ring, and their role in the final entrapment of the villain were all changes made to the original Storm Over Lisbon script with the purpose of presenting the Portuguese in a better light than initially planned. These changes came about in direct response to OWI complaints that by showing Deresco acting with no interference from the local police the original screenplay had given 'an unfavorable portrayal of neutral Portugal' ${ }^{67}$ In The Conspirators, after a policeman shot Vincent during the prison break sequence, Vincent

\footnotetext{
62 NARA, College Park, MD, Records of the OWI, Record Group 208, NC148567-4741004, Box 3514, The Conspirators, Dispatch from the OWI's L.A. Overseas Bureau, Motion Picture Division, 07.10.1944.

63 NARA, College Park, MD, Records of the OWI, Record Group 208, NC148567-4742245, Box 3526, Storm Over Lisbon, Cunningham to Gahagan, 31.03.1944.

${ }^{64}$ NARA, College Park, MD, Records of the OWI, Record Group 208, NC148567-4742245, Box 3526, Storm Over Lisbon, Cunningham to Rothacker, 22.05.1944.

${ }^{65}$ The others were International Lady, Journey for Margaret, The Fallen Sparrow, and Voice in the Wind. Casablanca barely makes the list, having premiered in Portugal in May 1945. The Hairy Ape premiered four months later. - L. Pina, Estreias em Portugal 1918-1957: Filmes de Longa Metragem (Lisbon 1993), $98,108,110,111,113$.

66 TT, SNI, IGAC, 2a Inc., Cx.1, Pr.26, Censorship file for 'A casa da Rua 92'. The House on 92nd Street premiered in Portugal in February 1947 (Pina, Estreias em Portugal, 119). No censorship files are available for the remaining movies, because the administration of film censorship only became centralised and systematised in 1945 (A. Cabrera, 'Censura e estratégias censurantes na sociedade contemporânea', in A. Cabrera, Censura nunca mais! A censura ao teatro e ao cinema no Estado Novo (Lisbon 2013), 29-30). 67 NARA, College Park, MD, Records of the OWI, Record Group 208, NC148567-4742245, Box 3526, Storm Over Lisbon, Cunningham to Gahagan, 31.03.1944.
} 
made a point to clarify to the locals who took care of him that the officer 'was only doing his duty'. ${ }^{68}$ One of the five screenwriters to rework that film's script, Leo Rosten, also convinced the producers to drop a scene involving Vincent's arrest by arguing that it made the police, particularly Almeida, look 'foolish' ${ }^{69}$ In the end, the PCA classified Storm Over Lisbon's characterisation of the Portuguese as 'sympathetic', 70 and The Conspirators' as ranging from 'indifferent' to 'sympathetic'. ${ }^{71}$ The Conspirators' relatively benign portrayal is all the more striking when compared to the gloomy depiction of Lisbon in the novel that inspired the film, whose narration opened in a Portuguese prison filled with political prisoners from different nations. ${ }^{72}$ In fact, the final script still included dialogue that alluded to the danger Portugal was in by not choosing a clear side in the war, ${ }^{73}$ to the country's own history of slavery, ${ }^{74}$ and to the hard living conditions of refugees in Lisbon, ${ }^{75}$ all of which were left out of the actual film.

One scene in The Conspirators illustrates particularly well the fact that by setting this kind of stories in Portugal it was hard not to politically engage with the country's regime, even if by omission. Belonging to a spy subgenre that celebrated the various European resistance movements against the Nazis ${ }^{76}$ the film's anti-fascist message gained an extra subtext when placed over a Portuguese background. Vincent, who sought refuge within a fishing community in Cascais, didactically described to his hosts how people across Europe were fearlessly fighting German tyranny and sabotaging it through violent means. A former schoolteacher, Vincent explained over a melodramatic

\footnotetext{
68 The Conspirators, 01:06:53.

69 WCFTR, United Artists Collection, Series 1.2, Box 76, Folder 3, Comments and changes on "The Conspirators", 11.04.1944, p.8.

${ }^{70}$ AMPAS, MPAA, PCA records, Storm Over Lisbon, Analysis Chart, 30.03.1944.

${ }^{71}$ AMPAS, MPAA, PCA records, The Conspirators, Analysis Chart, 07.08.1944.

${ }^{72}$ F. Prokosch, The Conspirators (New York/London 1943), 6.

${ }^{73}$ In the abovementioned scene with Lutzge, he was to have postulated: 'Such neutrality has led to slavery. The Captain has but to look at the map... If I were not so fond of Portugal I wouldn't warn you.' Later, Vincent was to have teased an attendant with the fact that his newsstand displayed papers from the two sides of the conflict. The attendant would have remarked that Portugal carried 'water on both shoulders', to which Vincent would have replied 'Let us hope you never get wet'. - AMPAS, Hal Wallis papers, 418, Conspirators, Revised final screenplay, p.7 and p.11.

${ }^{74}$ Captain Pereira was to have told Lutzge: 'We were a world power once. In the days of Vasco da Gama every Portuguese beggar owned five slaves. And we were ruined by it. Slavery has a way of ruining those who practice it'. - AMPAS, Hal Wallis papers, 418, Conspirators, Revised final screenplay, p. 8.

75 In a passage added by Ayn Rand, who was hired to rewrite dialogue, a waiter would have explained that these refugees 'spend whatever money they have - and starve in stinking boarding houses. Then - the Belgian explorer is found in his bedroom with a bullet through his brain - the Austrian countess is in jail for stealing the sapphire bracelet - the Czech professor drowns himself in the Tagus... The rest spend their days begging at consulates, gossiping, gambling, bribing, pawning, cheating, waiting - always waiting...' AMPAS, Hal Wallis papers, 418, Conspirators, Revised final screenplay, p. $24 \mathrm{~A}$.

${ }^{76}$ Dick, Star-Spangled Screen, 146-65.
} 
soundtrack that his own commitment to this movement derived from having been arrested for teaching his students to praise liberty. Close-ups, solemn acting, and sombre lighting reinforced the seriousness of this tribute to anti-fascist resistance, as did shots of the fishermen and their families that showed them listening in awe. ${ }^{77}$ Yet the latter shots also implied the villagers' unfamiliarity with the reality Vincent was describing. Although apparently impressed by his speech and ultimately willing to help smuggle him out of the country, neither here nor in subsequent scenes were the villagers shown to interpret Vincent's words as a possible call to action against the Salazar dictatorship. This, coupled with the film's overall respectful portrayal of the local authorities, misleadingly suggested the absence of recognisable state repression and domestic resistance in Portugal.

Furthermore, while the recurrence of killings and double-crosses implied a dangerous side of Portugal, that side was never overwhelming. Publicity for Storm Over Lisbon labelled the Portuguese capital as 'City of Intrigue' and The Conspirators' trailer called it 'The City of Echoes and Shadows'. ${ }^{78}$ Yet the films were practically bloodless they were shot through stylised, film noir photography, toning down realistic violence in favour of cat-and-mouse games between the various agents. The OWI reviewers described The Conspirators' portrayal of espionage as being 'in a melodramatic and artificial style', especially the use of secret doors and hidden peepholes 'in the true Hollywood tradition'. ${ }^{79}$ The country's threatening dimension in these movies, therefore, was not enough to prevent the overall impression that Portugal was an enjoyable place.

As foreign correspondent Joseph D. Ravotto acknowledged in late 1941, visitors' impressions of Portugal differed strongly according to whether they arrived from the east or the west. Correspondents passing through from the plentiful USA, such as Quentin Reynolds and George Lait, had not been impressed, considering Lisbon 'dull and unexciting'. By contrast, those who like Ravotto had just lived in Spain, France, and similar places across Europe, 'found Portugal an oasis in the desert of want, rationing systems, hostile and suspicious atmosphere, occupation - official and unofficial stringent censorships and other things of the same ilk' ${ }^{80}$ Many shared this view, although

\footnotetext{
77 The Conspirators, 24:09-25:56.

78 'Exploiting the New Films', Motion Picture Herald (23 September 1944).

79 NARA, College Park, MD, Records of the OWI, Record Group 208, NC148567-4741004, Box 3514, The Conspirators, Dispatch from the OWI's L.A. Overseas Bureau, Motion Picture Division, 07.10.1944.

80 'Lisbon Is Paradise After Restrictions Elsewhere in European Capitals', Variety (07 January 1942).
} 
refugees' perceptions were quite diverse and multifaceted. ${ }^{81}$ In a Variety article of June 1942, a journalist fresh from five months of internment in Germany made the same point about Lisbon's night life: it was 'heaven for anyone just coming out of occupied France, Germany or Italy', even though what money could buy came 'in limited quantities with not too much class attached' and plenty was still lacking in comparison to the top entertainment in Europe before the war. ${ }^{82}$ Disregarding the caveats, Hollywood embraced the notion that Portugal was a place to have fun. The romantic comedy Affectionately Yours (1941) opened with an American correspondent in Lisbon who spent his time flirting with women. ${ }^{83}$ In The Hairy Ape, Mildred was supposed to be doing humanitarian work in Portugal, but was reproached by her superior for not having 'shown the slightest interest in anything but having a good time'. ${ }^{84}$ Even The Conspirators' revolutionary hero Vincent Van Der Lyn informed the audience (through a voice-over) that as he approached Lisbon he could think only of 'bright lights and soft music, good food and old wine, perhaps even... romance', 85

The subset of prosperous and aristocratic refugees who took over the most expensive accommodation, particularly in the Estoril area, ${ }^{86}$ provided North American films with an opportunity to fill the screen with lavish décors and elegant wardrobes while still addressing the dramatic European events. Practically all of the Portugal-set films discussed in this article featured luxurious restaurants, hotels, and ballrooms. The mix of exiled royalty, diplomats, and spies at the Estoril casino inspired both The Conspirators (whose climax revolved around a gambling table in Estoril) and Storm Over Lisbon (which was mostly set in a fictitious version of this casino). The latter opened with two wealthy old ladies in Estoril, entering a casino while commenting that it was 'better than Monte Carlo' and it oozed 'finesse' ${ }^{87}$ This infatuation with Portugal's affluent milieu vividly came across in a passage of the original story treatment for The Lady Has Plans:

\footnotetext{
81 Pimentel, Judeus em Portugal, 141-65.

82 'Lisbon Rates Tops Compared To Rest Of Europe; Fancy Nite Life Prices', Variety (03 July 1942).

${ }^{83}$ Affectionately Yours, Dir. Lloyd Bacon, Warner Bros, 1941. Another romantic comedy, Three Hearts for Julia (Dir. Richard Thorpe, MGM, 1942), also began with a Lisbon-based foreign correspondent, yet one with a sterner lifestyle.

${ }^{84}$ The Hairy Ape, 19:20-2.

${ }^{85}$ The Conspirators, 02:44-58.

86 'Lisbon: Europe's Bottleneck', Life Magazine (28 April 1941); Lochery, Lisbon, 66-8.

87 Storm Over Lisbon, 02:31-40.
} 
THE DINING ROOM OF THE PALACE HOTEL is filled with a dazzling throng that represents the cream - in fact, the whipped cream - of international society. Ladies and gentlemen of every country in the world mingle in an atmosphere where sable is commonplace and nothing short of a twenty-carat ruby would call for a second glance. ${ }^{88}$

More than a centre of escapism and glamour, Portugal became the symbol of a bygone Europe. In One Night in Lisbon, the American lead convinced his British love interest to travel with him by pointing out that Portugal was a 'country still at peace' with people 'still having fun, still laughing', with 'bright sun and a blue sea and great castles made out of tiles that look like jewels' ${ }^{89}$ In other words, he emphasised the contrast with the war-torn London displayed in the film, with its lights-out policy, bomb shelters, warning signs, helmets, and gas masks. In The Conspirators, a foreign boy reacted ecstatically upon arrival in Portugal, his mother explaining that because of the war he had never seen city lights before. In the same scene, other refugees recalled their pre-war hometowns: 'Warsaw used to be like this', 'I remember Prague', 'In Brussels you could read the newspapers at night.' Vincent Van Der Lyn soon found himself in a fancy Lisbon café, where he asked for various food items he had lacked abroad, clarifying: 'I've been planning this dinner for three years.' When asked, he later confirmed to his fishermen hosts that Portugal was 'the last country in Europe where you can still get wine'.$^{90}$

The latter interaction also reflected the general notion that the Portuguese lower classes led simple lives, untouched by Europe's tribulations over fascism. As described in The Conspirators' initial outline, from the fishing community Vincent received 'an honest compassion and sympathy, not with his work but with his plight as a hunted human being', since the village was removed from 'the upper world, [where] all is confusion of intrigue and black conspiracy, ${ }^{91}$ Besides the fishermen, led by the wise Miguel, in prison

\footnotetext{
${ }^{88}$ AMPAS, Paramount Pictures Scripts, 00952, Original story, 'The Palace of a Thousand Lies', 27.03.1941, p.47. In one version of this film's script, where the dining room was described as 'the last word in luxurious, good taste', Sidney Royce went as far as to ask 'How will I ever be able to go back to the Y.M.C.A. [Young Men's Christian Association] and drug store dinners after this [...]?' This line was later changed on the advice of the PCA, which considered it possibly displeasing to the YMCA. - AMPAS, Paramount Pictures Scripts, 00952, Revised white script by Harry Tugend, 28.08.1941, and PCA records, The Lady Has Plans, Letter from the PCA to Mr. Luigi Lurashi, 16.09.1941.

${ }^{89}$ One Night in Lisbon, 54:44-57.

90 The Conspirators, 03:36-50, 08:56-09:27, and 24:02-08.

${ }^{91}$ WCFTR, United Artists Collection, Series 1.2, Box 74, Folder 9, "The Conspirators" Detailed Outline by Frederick Faust, 15.04.1943, pp.28-9. One of the fisherman, however, does briefly express resentment towards the Germans because they once took him in for smuggling near Biarritz (24:16-9).
} 
Vincent also met a gentle cellmate named Antonio, leading screenwriter Jack Moffitt tasked with rewriting the script - to ask: 'Are we to believe Portugal is packed with sentimental old men? ${ }^{92}$ Oblivious to the massive wave of strikes and social protest sweeping Portugal in the early 1940s, which led to the Salazar dictatorship's first major political crisis, ${ }^{93}$ these movies presented the Portuguese population as by and large economically humble and hardworking yet content. With no visible signs of rationing or fear of oppression, sadness was reserved for romantic woes, as shown in a scene in The Conspirators where locals gathered to enjoy a melancholic fado song about unfulfilled love. This was a society with no apparent inner tensions or conflict: even when American sailors started a fight in a tavern, in the beginning of The Hairy Ape, the police sorted out the situation without much violence, calmly identifying the responsible parties and negotiating a solution.

This misrepresentation of Portuguese daily life was part of a more general lack of concern with geographic-cum-cultural verisimilitude, as was typical of North American productions of that era. Although informed by the impressionistic contrast between life in Portugal and in the rest of the continent, these productions remained blatantly artificial in their depiction of the country. The movies were not shot in Portugal, relying instead on converted Hollywood sets and locations, as well as on stock footage. ${ }^{94}$ Their take on places outside the extravagant hotels and restaurants drew on recognisable, usually maritime, imagery, the background often populated by seamen, fishermen, and

\footnotetext{
92 WCFTR, United Artists Collection, Series 1.2, Box 76, Folder 2, "The Conspirators" Suggestions by Jack Moffitt, 10.04.1944, p.28.

${ }^{93}$ F. Rosas, Portugal entre a Paz e a Guerra 1939-1945 (Lisbon 1995), 337-415, 445.

94 Establishing shots in One Night in Lisbon were commissioned to the Portuguese César de Sá, but the film's Portugal sequence was essentially shot at Paramount's studios ('A Paramount vai filmar em Hollywood "One Night in Lisbon" cuja acção decorre em Lisboa', Animatógrafo (6 January 1941); 'As primeiras fotos do filme Americano "Uma Noite em Lisboa", Animatógrafo (26 May 1941)). Sets in Storm Over Lisbon seem modelled after footage from The March of Time newsreels (J.M. Mateus, 'Uma cidade de espionagem internacional. Lisboa Segundo Hollywood', Metakinema, 7 (2010) [http://www.metakinema.es/metakineman7s4a2_Joao_Mascarenhas_Mateus_Lisbon_International_Int rigue_Hollywood.html accessed 29.06.2015]). In The Conspirators, the central street Rua do Século looks borrowed from a village in a Mexican-set western. The Hairy Ape's version of the bystreet Travessa do Carmo was helpfully disguised by moody sea mist. For the Portuguese sequences, the latter film employed as technical director Rodrigo Nebrega de Medicis (Rod de Medicis), a teacher of Portuguese in the Hollywood High School (British Film Institute, Reuben Library, The Hairy Ape Pressbook, 'Difficulties Overcome in Adapting "Hairy Ape"'). Medicis also worked on The Lady Has Plans, where the coast at Three-Arch Bay, south of Laguna Beach, doubled for Estoril (AMPAS, General Collection, The Lady Has Plans, Production Notes, 02.06.1941). He had a small part as an immigration officer in The Conspirators (American Film Institute Catalog of Feature Films, available at http://www.afi.com/members/catalog/DetailView.aspx?s=\&Movie=2457 accessed 01.12.2014).
} 
fishwives. ${ }^{95}$ Most actors playing local characters did not speak fluent Portuguese, widely mispronouncing their brief lines or, as in the case of the woman in the pier in Voice in the Wind, speaking gibberish made up of expressions from various Latin-based languages. In The Conspirators' version of Cascais - in the film a small, humble village; in reality the site of luxurious hotels which in 1941 accommodated over a thousand wealthy refugees ${ }^{96}$ - two fishermen sang improbably, with a distinctly Brazilian accent, a song about the Brazilian city of Maringá. Characters from lower classes used traditional clothing, but not always congruently: in Storm Over Lisbon, a waiter in a bar near Estoril wore a large knit hat typical of bullfighting forcados and Ribatejo cattle herders.

The level of inaccuracy, although characteristic of Hollywood's fanciful style, met with different responses. After watching Storm Over Lisbon, Henrique Medina concluded that the film 'would be accepted as a Hollywood version of Lisbon, and might afford Portuguese audiences some amusement because of the complete absence of authenticity'. ${ }^{97}$ By contrast, the Los Angeles-based correspondent of the Portuguese film newspaper Animatógrafo, Bernardo Teixeira, derisively mocked the inaccuracies of One Night in Lisbon, especially concerning the accents of the Portuguese characters. ${ }^{98}$ Frederic Prokosch, author of the novel that had served as basis for The Conspirators, was even less forgiving. The superficiality of this movie's recreation of Portugal contrasted starkly with his book, which included exhaustive descriptions of the aesthetics, sounds, smells, and general atmosphere surrounding the Portuguese capital. Prokosch, who had lived in Lisbon, strongly criticised the movie's unrealistic approach in a letter published by the New Republic magazine:

I hadn't imagined that the quality of [Lisbon] could be so widely misrepresented, could be turned into such excruciating silliness. I kept smiling when I thought of

\footnotetext{
95 In The Lady Has Plans' original story treatment, the Lisbon headquarters of the German Espionage and Counter-Espionage Bureau were even hidden in a sardine cannery. - AMPAS, Paramount Pictures Scripts, 00952, Original story, 'The Palace of a Thousand Lies', 27.03.1941, p.14.

96 Lochery, Lisbon, 71; Pimentel, Judeus em Portugal, 138.

97 NARA, College Park, MD, Records of the OWI, Record Group 208, NC148567-4742245, Box 3526, Storm Over Lisbon, Cunningham to Rothacker, 22.05.1944.

98 'O correspondente particular de "Animatógrafo" na América assistiu à estreia mundial de "Uma Noite em Lisboa"', Animatógrafo (14 July 1941). Besides One Night in Lisbon, the only other movie addressed in this article to be reviewed by Animatógrafo was International Lady, in the paper's very last issue: the review considered the film too gloomy, including the sequence in Lisbon ('Resumo crítico de cinco filmes', Animatógrafo (22 May 1942)).
} 
the bewilderment the Portuguese will feel when the film finally reaches them. (If it ever does. $)^{99}$

While the OWI reviewers did not object to the artificiality per se, they did worry that Hollywood could come across as patronising. Their report on The Hairy Ape pointed out that the owner of the tavern where the fight broke out and an accordion player were 'used for comedy purposes and caricatured in a manner that could offend the Portuguese'. ${ }^{100}$ The report on The Conspirators criticised the fact that the fishermen appeared 'ignorant of the invisible armies of Europe until the hero explains the cause of "Long Live Liberty."101 Finally, the OWI expressed concern about the condescending behaviour of American characters in Storm Over Lisbon, remarking that there were 'several scenes which lay heavy stress on American bumptiousness in their dealings with the Portuguese'. ${ }^{102}$ Revealingly, these objections addressed the tone of the scenes, but not their implications regarding Portuguese politics.

That Hollywood's version of Portugal distanced the Salazar regime from European fascism becomes even more apparent when compared to the treatment given to Spain. The 1936-1939 civil war pitting the republican forces loyal to the democratically elected Popular Front against the nationalist rebels led by General Francisco Franco received widespread international projection and became a cause célèbre in the artistic community. As a result, a series of movies increasingly exposed the political ramifications of Francoism. This was certainly a gradual process: North American fiction films set in the Spanish Civil War and made during the actual conflict, including The Last Train from Madrid (1937), Love Under Fire (1937), and Blockade (1938), had still avoided stating what each faction ideologically stood for. ${ }^{103}$ Studio bosses had worried that by appearing propagandistic their movies could have compromised box-office return and the PCA had been adamant about ensuring Hollywood's impartiality. Even Blockade,

\footnotetext{
99 AMPAS, General Collection, The Conspirators, Correspondence, F. Prokosch, 'Is Hollywood Dying?', New Republic (13 November 1944).

100 NARA, College Park, MD, Records of the OWI, Record Group 208, NC148567-4741450, Box 3517, Hairy Ape, Dispatch from the OWI's L.A. Overseas Bureau, Motion Picture Division, 08.05.1944.

101 NARA, College Park, MD, Records of the OWI, Record Group 208, NC148567-4741004, Box 3514, The Conspirators, Dispatch from the OWI's L.A. Overseas Bureau, Motion Picture Division, 07.10.1944.

102 NARA, College Park, MD, Records of the OWI, Record Group 208, NC148567-4742245, Box 3526, Storm Over Lisbon, Cunningham to Gahagan, 31.03.1944.

103 The Last Train from Madrid, Dir. James P. Hogan, Paramount Pictures, 1937; Love Under Fire, Dir. George Marshall, 20 ${ }^{\text {th }}$ Century-Fox, 1937; Blockade, Dir. William Dieterle, United Artists, 1938.
} 
the only production to controversially take a firm side, had obediently agreed not to name the factions or to identify the uniforms of the soldiers in the story - its allegorical support for the Popular Front had relied on the familiarity of well-informed members of the audience with current events in Spain. ${ }^{104}$ Walter Wanger, the liberal independent producer behind Blockade, had then attempted to adapt Vincent Sheean's best-seller Personal History into a film that would expose in no uncertain terms the brutality of fascism in Spain and Germany, but he had been dissuaded by the PCA. ${ }^{105}$

With the outbreak of World War II, studios revised their approach to the Spanish Civil War. Still fresh in public memory, the Spanish conflict was retroactively accepted as a dress rehearsal for the Second World War, a clash between fascist Nationalists and anti-fascist Republicans, the former directly supported by Germany and Italy, the latter by the Soviet Union. Accordingly, movies now depicted Americans who had sided with the loyalist faction as heroes, cueing the righteous alignment in the ongoing war. In the politically charged romantic comedy Arise, My Love (1940), the connection between the new regime in Madrid and Adolf Hitler's was made clear in the very first act, set in the aftermath of the Civil War, in a military prison near Burgos, where the nationalist government sought to execute an American pilot who had flown for the Loyalists. ${ }^{106} \mathrm{~A}$ past in Spain became a recurring shorthand to establish a character's anti-fascist motivations, as in the case of the protagonists of Casablanca and The Fallen Sparrow, among many others. ${ }^{107}$ The OWI's leniency towards this trend was consistent with the attitude of key figures running the agency, many of whom had been vocal champions of the loyalist cause who had failed to prevent Washington's neutrality in the former conflict and its swift recognition of the Franco regime. Now tasked with a propaganda effort against fascist expansionism in Europe, these officials took the opportunity to present Spain as an early target of fascist aggression and to discredit its current dictatorship, even at the risk of weakening the USA's strategy of promotion of Spanish neutrality. ${ }^{108}$

\footnotetext{
104 For a detailed analysis of these three films and their background, see C.R. Koppes, G.D. Black, Hollywood goes to war: how politics, profits and propaganda shaped World War II movies (London 1987), 23-6; Dick, Star-Spangled Screen, 10-20; Doherty, Hollywood and Hitler, 137-57.

105 Koppes/Black, Hollywood goes to war, 26-7, 30-1. This project eventually became a movie without any reference to Spain, namely Foreign Correspondent, Dir. Alfred Hitchcock, United Artists, 1940.

${ }^{106}$ Arise, My Love, Dir. Mitchell Leisen, Paramount Pictures, 1940.

107 Dick, Star-Spangled Screen, 21-3.

108 On the clashes between the OWI's offensive and the more pragmatic, accommodating policy of the US Embassy in Madrid, see P. León-Aguinaga, 'The Trouble with Propaganda: the Second World War, Franco's Spain, and the Origins of US Post-War Public Diplomacy', The International History Review, $37: 2$ (2015), 342-65.
} 
The conflict that had enabled General Franco's ascension to power was given its most expansive Hollywood treatment in Paramount's epic drama For Whom the Bell Tolls (1943), ${ }^{109}$ one of the most popular releases among moviegoers in 1944 and $1945 . .^{110}$ Taking place entirely in Spain during the Civil War, the movie narrated a heroic mission headed by Robert Jordan, an American on the side of the Loyalists. Characteristically, the studio preferred to emphasise the commercially appealing love story between Jordan and Maria, a member of his group. Paramount was even rumoured to have toned down the script's anti-fascist slant after protests by the Franco regime and subsequent pressure by Washington's State Department. The studio admitted that it had given a script draft to the Spanish Consulate in San Francisco, yet claimed to have ignored all its suggestions for revisions. ${ }^{111}$ Certainly, the film excised much of the political content of Ernest Hemingway's original novel - particularly in the second released version, which was shortened by about 30 minutes due to worries that the initial length (170 minutes) be considered off-putting by general audiences. Regardless, this remained a high profile production where the Francoist forces served as the main villains. The loyalist fighters were depicted as buffoonish simpletons, much like the Portuguese lower classes in the films set around Lisbon, but in this case their hardships and resentment against the Nationalists were omnipresent. In fact, the violence of an attack against fascist landowners, in a flashback sequence, caused discomfort among the OWI reviewers, who wished that the Republican struggle be presented in an unambiguously positive light. Their report declared that 'what the Loyalists were fighting for is essentially the same thing that we are' and therefore warned against focusing 'too much attention on the chinks in our allies' armour'. ${ }^{112}$

One movie epitomised the evolution of Spain's portrayal in Hollywood fiction during this period. Released in November 1945, a few months after the end of the Second World War, Confidential Agent adapted a 1939 Graham Greene novel about a foreign agent on a mission in the UK to prevent a deal to supply coal to the militias taking over his country. ${ }^{113}$ In contrast to the 1930 s' policy of unnamed sides and motivations, this

\footnotetext{
${ }^{109}$ For Whom the Bell Tolls, Dir. Sam Wood, Paramount Pictures, 1943.

110 Doherty, Projections of War, 320-2.

111 N.M. Rosendorf, Franco Sells Spain to America: Hollywood, Tourism and Public Relations as Postwar Spanish Soft Power (Basingstoke 2014), 51, 214.

112 For an extended discussion of For Whom the Bell Tolls, including this OWI report, see D. Archibald, The war that won't die: The Spanish Civil War in cinema (Manchester 2012), 30-47; Dick, Star-Spangled Screen, 25-31.

${ }^{113}$ Confidential Agent, Dir. Herman Shumlin, Warner Brothers, 1945.
} 
production actually went further than the source material in terms of spelling out what was at stake: while the agent's nationality and affiliation had remained unidentified in the novel, the movie made it explicit that the hero was a Spanish Loyalist trying to undermine the fascist rebels and their sympathisers in the outside world. ${ }^{114}$ Like the previous Hollywood productions about Spain, Confidential Agent was less pro-Loyalist than antiNationalist, and even then less outspoken about the Nationalists' domestic fascism than about their international fascist support, the Civil War serving essentially as a metaphor for the confrontation in World War II. ${ }^{115}$ What is noteworthy for the purposes of this article, however, is that as simplified and problematic as Hollywood's version of Spain certainly was, the focus on the Civil War could not help but acknowledge a link to fascism associated with the birth of the current Spanish regime, which stood in stark contrast to the image of Portugal in contemporaneous films.

Like the similarities between the regimes of Franco and Salazar, their complicity - including key Portuguese support for the Nationalists in the Civil War ${ }^{116}$ - were left off-screen as well. Such complicity, however, meant that Hollywood's indictment of the Spanish dictatorship made it difficult for many of these films to reach Portuguese theatres. Not only did the nationalist rebels lobby to prevent the screening of Blockade in Lisbon, the Francoist authorities signed a protocol with the Salazar dictatorship prohibiting the diffusion of motion pictures that could harm the image of any of the two regimes. ${ }^{117}$

In conclusion, in the early 1940s the surge of movies dealing with the Second World War increased the presence of Portugal - specifically Lisbon and surroundings in North American film fiction, projecting a sanitised image of the country and, by extension, its regime. Although the focus on stories of desperate refugees and

\footnotetext{
${ }^{114}$ For a comparison with the novel, see G. Greene, Confidential Agent (London 2006 [1939]). Notice, for example, how the scene involving a crowd of miners discussing the implications of the coal deal is much more explicit in the film than in the book (pp.203-4).

115 For an extended analysis of Confidential Agent, see Dick, Star-Spangled Screen, 31-5. See also Rosendorf, Franco Sells Spain to America, 51-2.

${ }^{116}$ A.P. Rodríguez, El gran aliado de Franco. Portugal y la Guerra Civil española: prensa, radio, cine y propaganda (Sada 1998); A.P. Rodríguez, 'Salazar y Franco en el panorama internacional: estrategia diplomática y propaganda (1936-1945)', Espacio, tiempo y forma, 5:25 (2013), 23-47.

${ }^{117}$ A.P. Rodríguez, 'O cinema português e a propaganda franquista durante a Guerra Civil de Espanha', in Torgal, Cinema sob o Olhar de Salazar, 158-9. When Paramount Pictures of Portugal requested permission to distribute For Whom the Bell Tolls, in 1947, the Portuguese censorship did not allow it (TT, SNI, IGAC, 1aㅡ. Inc., Cx.341, Pr.1/47, Censorship file for 'Por quem os sinos dobram'). By contrast, Blood and Sand (Dir. Rouben Mamoulian, $20^{\text {th }}$ Century-Fox, 1941), which was also set in Spain yet focused on its bullfighting culture, premiered in Portugal on 29 December 1941 (Pina, Estreias em Portugal, 95).
} 
international espionage could have conveyed a threatening image of Portugal, this was significantly diluted by the emphasis on light-hearted entertainment, with most films dwelling on the luxurious and hedonistic environment of privileged exiles. By stressing the persistence of peace, entertainment, and consumer goods in the country, the movies portrayed Lisbon's neutrality in a positive light. In an extreme case, the anti-Nazi Captain Pereira (the most prominent Portuguese character on screen) actually broke with official policy and seemingly exposed his country's pro-British inclinations. For the most part, however, these films stayed clear of Lisbon's politics, implicitly obscuring repression and social conflict. They thus ended up de-ideologising the Salazar regime while clearly distinguishing it from the USA's fascist enemies. Since concurrent film productions about Spain emphasised popular grief and Madrid's historical ties to international fascism, on an intertextual level the Salazar regime was likewise differentiated from its fascist neighbour.

Besides shedding light on a forgotten dimension of Portugal's international image, this case study also illuminates American attitudes towards the Salazar regime. Both the Hollywood film studios, dependent on foreign markets, and the Office of War Information, concerned with securing Portuguese goodwill towards the Allies, sought to avoid provoking the Salazar dictatorship. They did not always agree on the best approach, as the studios proved keen to exploit Lisbon's dramatic potential while the OWI argued that depictions of the local population could be considered offensive and the protagonists' ordeals could imply ineptitude of the Portuguese authorities. Nevertheless, one point where Hollywood's filmmakers and Washington's propagandists found common ground was on their lenient attitude towards Portuguese politics, especially when compared to their more openly critical stance concerning the Spanish regime. This contrast can be explained through the global resonance of the then-recent Spanish Civil War, as well as through the Allies' closer relations with the more cooperative Salazar dictatorship and keen interest in the strategic Azores bases. Indeed, the same factors were later decisive in enabling Salazar's Portugal a much speedier and more intensive integration than Franco's Spain into the post-war international order. Ultimately, even the OWI's Bureau of Motion Pictures, with its rhetoric of promotion of freedom, democracy, and militant anti-fascism, defended a benign view of the Lisbon regime, thus reflecting and encouraging a strand in North American - and more generally Western - diplomacy which conveniently disregarded the ideological origins of what would soon become the longest-surviving right-wing dictatorship in Europe. 